\title{
Control of Intestinal $E$. coli Infection in Broiler Chicks Using Lactobacillus casei Isolated from Nono
}

\author{
Onyeka Michael Ikele ${ }^{1}$, Ifeoma Maureen Ezeonu ${ }^{2}$, and Chibuzo Nneka Umeh ${ }^{1}$ \\ ${ }^{1}$ Nnamdi Azikiwe University, P.M.B. 5025, Awka, Nigeria \\ ${ }^{2}$ University of Nigeria, Nsukka, Nigeria \\ "Corresponding author's Email: mo.ikele@unizik.edu.ng; ORCID: 0000-0001-7628-2962
}

\begin{abstract}
The current study aimed to evaluate whether the probiotic Lactobacillus casei could be effective in controlling chicken intestinal colibacillosis. Avian pathogenic Escherichia coli (E. coli.) and Lactobacillus casei (L. casei) isolates were obtained from nono (a sour milk product produced by Fulani tribe of Nigeria), and were used for the chicken infection and probiotic treatment, respectively. The experimental design was conducted on three-week-old broiler chicks, which were divided into five groups, namely A (healthy control), B (infected without treatment), C (infected and treated with antibiotic), D (infected and treated with $L$. casei), and E (initially given L. casei before infecting with E. coli). Groups C and D were treated using $15 \mathrm{~g} / \mathrm{L}$ norfloxacin and $1.5 \mathrm{ml}$ of $1.1 \times 10^{9} \mathrm{cfu} / \mathrm{ml} \mathrm{L}$. casei, respectively. Group E was given the oral infusion of $1.5 \mathrm{ml}$ of $1.1 \times 10^{9} \mathrm{cfu} / \mathrm{ml} \mathrm{L}$. casei before infection with $1.5 \mathrm{ml}$ of $1.3 \times 10^{7} \mathrm{cfu} / \mathrm{ml}$ avian pathogenic E. coli. Weight, hematological parameters, liver function, and fecal E. coli counts of the chicks were monitored and used to evaluate the level of protection elicited by the probiotic organism. There was weight gain in chicken groups, except for group B. There was a significant difference in the sodium, chlorine, and bicarbonate levels amongst the groups. The hematological profile revealed a significant difference in the hemoglobin, white blood cells, lymphocyte, and neutrophil counts of the chicken groups. Assessment of liver enzymes showed no significant difference amongst the chick groups except in group B. Similar results were obtained for the urea, creatinine, and C-reactive protein levels. The microbial tests revealed a decrease in the total $E$. coli count for groups C, D, and E. The results of the current study indicated that $L$. casei could be used as a probiotic in the control of chicken colibacillosis.
\end{abstract}

Received: 12 Jan. 2021

Accepted: 27 Feb. 2021

Keywords: Broiler, Colibacillosis, Escherichia coli, Lactobacillus, Nono, Probiotics

\section{INTRODUCTION}

Antibiotic resistance has become a major threat to disease treatment in recent years and the use of antibiotics for controlling infection in food animal production has been figured as one of the reasons for increased resistant strains (WHO, 2014; CDC, 2019).

Escherichia coli (E. coli) is one of the top seven pathogens of public health concern (CDC, 2014). Avian pathogenic E. coli (APEC) is a type of E. coli strain responsible for colibacillosis, one of the major infections that threaten biodiversity conservation of poultry (De Preter et al., 2007; Dziva and Mark, 2008; Lutful-Kabir, 2010). The E. coli and some other bacterial infections in poultry have been controlled over the years with conventional antibiotics, such as monensin, chlortetracycline and oxytetracycline (Vesković Moračani et al., 2014). Nigerian farmers employ metronidazole and chloramphenicol as major antibiotics for controlling bacterial infections in poultry. This infection control method has major drawbacks, some of which include the selection of multidrug-resistant strains of $E$. coli in food animals and subsequent high antibiotic float in the human ecosystem (Ikele et al., 2020a). Therefore, the focus has been shifted to a search for antibiotic alternatives in food animal production.

Probiotics are microorganisms that confer health benefits to the host when consumed in adequate quantity (Holzapfel et al., 2001; Haben, 2019). The use of probiotics in animal production is an expanding research area as antibiotic alternatives for infection control in food 
animals (Vantsawa et al., 2017; Nugraheni et al., 2019). Lactobacillus casei (L. casei) is a Gram-positive anaerobic rod belonging to the lactic acid bacteria (LAB) group and is well-known for its wide probiotic values. It is a facultative homo-fermenter found in dairy products, such as cheese and nono (Ikele et al., 2020b). Nono is a locally fermented milk beverage consumed in Nigeria. It is a functional food that contains high numbers of LAB (Vantsawa et al., 2017). This study sought to evaluate the effectiveness of $L$. casei in the control of intestinal colibacillosis in broiler chicks.

\section{MATERIALS AND METHODS}

\section{Ethical approval}

This study was in accordance with the provisions of the National Institute of Health Guidelines for Care and Use of Laboratory Animals (PUB No. 85-23, revised 1985) and under the approval of the Nnamdi Azikiwe University Awka, Nigeria Ethical Committee, Nigeria, on the use of laboratory animals.

\section{Isolation of bacteria}

Lactobacillus and E. coli isolates were isolated from different nono samples obtained from different vendors at different locations in Awka, Anambra State, Nigeria. For bacterial isolation, $1 \mathrm{ml}$ of nono was aspirated with a sterile pipette and subjected to 10 -fold serial dilutions in sterile peptone water. The diluted samples $(0.1 \mathrm{ml}$ each) were cultured on de Man, Rogosa and Sharpe (MRS) agar and Eosin Methylene Blue (EMB) agar as selective media for Lactobacillus and E. coli, respectively. Cultures were incubated at $35{ }^{\circ} \mathrm{C}$ for $24 \mathrm{~h}$ in an anaerobe jar for Lactobacillus isolates and aerobically for E. coli isolates according to the methods proposed by Makut et al. (2014).

\section{Identification of isolates}

Lactobacillus and E. coli isolates were presumptively identified using routine cultural and biochemical tests and confirmed by 16s rDNA molecular typing at Macrogen Incorporate, South Korea.

\section{Screening of Escherichia coli isolates for avian pathogenicity}

The samples include 20 broiler chicks aged 3 weeks that were raised in a battery cage system and divided into four groups. Each group was orally infected with $10^{7}$ $\mathrm{cfu} / \mathrm{ml}$ of different presumptively identified $E$. coli isolates in phosphate-buffered saline (PBS, pH 6.8), with the aid of a sterile Pasteur pipette. The chicks were then monitored for 30 days for clinical signs, such as weakness, watery, and bloody stools (Ezema, 2013). Isolate that produced the most severe signs in a group was selected for molecular typing and used for further investigations.

\section{Probiotic screening of Lactobacillus isolates}

$L$. casei isolates were screened for acid tolerance, cell surface hydrophobicity, bile tolerance, sodium chloride tolerance, crude bacteriocin activity, and cell-free supernatant antibacterial activity against APEC (Dunne et al., 2001). The agar well diffusion assay was used to assess the antibacterial activity of cell-free supernatant (CFS) of $L$. casei isolates. A 10-ml aliquot of MRS broth was added to the Lactobacillus culture and incubated at 37 ${ }^{\circ} \mathrm{C}$ for $48 \mathrm{~h}$ in an anaerobic jar. After incubation, the culture was subjected to centrifugation (8000 rpm for 10 minutes), and the supernatant was obtained. A 100- $\mu 1$ aliquot of CFS was placed into wells on Mueller-Hinton agar plates $(20 \mathrm{ml})$ seeded with E. coli $(0.1 \mathrm{ml})$, and incubated at $35{ }^{\circ} \mathrm{C}$ for $24 \mathrm{~h}$. Subsequently, the diameters of inhibition zones were measured in $\mathrm{mm}$ (Ronnqvist et al., 2007). The $L$. casei isolate with the highest zone of inhibition against the chosen E. coli isolate was selected for the animal studies.

\section{Crude bacteriocin activity assay}

Lactobacillus spp. were grown in MRS broth for 24 $\mathrm{h}$ at $35{ }^{\circ} \mathrm{C}$ in an anaerobic chamber. Cell-free supernatant was obtained by being centrifuged at $4000 \mathrm{rpm}$ for 10 minutes. Ammonium sulfate $(0.425 \mathrm{~g}$ in $5 \mathrm{ml}$ solution) was used to directly precipitate the crude bacteriocin, after which the mixture was refrigerated overnight at $4{ }^{\circ} \mathrm{C}$, and vortexed again at the same speed and time. The supernatant was discarded while the trapped precipitate was dissolved using phosphate buffer $\mathrm{pH}$ 6.0, and was assayed for antibacterial activity using the agar well diffusion method (Joshi et al., 2006).

\section{Standardization of pure cultures of isolates}

Cultures of $L$. casei and APEC were grown in $25 \mathrm{ml}$ MRS broth and nutrient broth, respectively, and incubated at $30{ }^{\circ} \mathrm{C}$ for $24 \mathrm{~h}$ in an anaerobic jar for Lacotbacillus and aerobically for $E$. coli. The cultures were serially diluted to achieve concentrations of $10^{9} \mathrm{cfu} / \mathrm{ml}$ for $L$. casei and $10^{7}$ $\mathrm{cfu} / \mathrm{ml}$ for $E$. coli according to the method introduced by Hartmann et al. (2011).

\section{Animals}

Day-old broiler chicks (Gallus domesticus) were obtained from Aroma Farms, Awka, Anambra State 
Nigeria, and raised in battery cages with wood sawdust as bedding materials, at the temperature of $28-33{ }^{\circ} \mathrm{C}$. The chicks were vaccinated for Newcastle disease until they aged three weeks before they were used for the experiment. They were subjected to no antibiotic administration. They were fed with a starter diet for the first seven days and a finisher diet for the remaining weeks. Blood samples $(1.5 \mathrm{ml})$ were collected from each chick starting from the third week, with a sterile syringe and needle through their wing vein.

\section{Experimental design}

Five groups of 10 three-week-old chicks were set up as follows: healthy control (Group A), infected with APEC (Group B), infected with APEC and treated with norfloxacin (Norflox-200, Interchemie, Netherlands; Group C); infected with APEC and treated with L. casei (Group D), given oral dose of $L$. casei $48 \mathrm{~h}$ before infection with APEC (Group E).

Groups B, C, and D orally received initially $1.5 \mathrm{ml}$ of $1.3 \times 10^{7} \mathrm{cfu} / \mathrm{ml}$ of $E$. coli mixed with $0.5 \mathrm{ml}$ PBS (pH 6) with the aid of a sterile pipette and left for two days to allow for proper pathogen colonization and disease establishment (evidenced by the discharge of watery and bloody stool). Afterwards, group D was dosed orally with $1.5 \mathrm{ml}$ of $1.1 \times 10^{9} \mathrm{cfu} / \mathrm{ml}$ of $L$. casei to initiate competitive inhibition. Group $\mathrm{C}$ was treated with norfloxacin (15 $\mathrm{g} / \mathrm{L}$ in drinking water) for two weeks. Group E was administered with an oral initial dose of 1.5 $\mathrm{ml}$ of $1.1 \times 10^{9} \mathrm{cfu} / \mathrm{ml}$ of $L$. casei and left for two days, then was infected with $1.5 \mathrm{ml}$ of $1.3 \times 10^{7} \mathrm{cfu} / \mathrm{ml}$ of E. coli. This group was used to ascertain the preventive ability of the L. casei on colibacillosis (Pascual et al., 2009; Ikele et al., 2019).

\section{Growth performance parameters}

Weights, percentage weight gain, and specific growth rates of the chicks were monitored using the method introduced by Radhakrishman et al. (2015). The body weights of the chicks were weekly measured using Mettler weighing balance of $0.01 \mathrm{~g}$ sensitivity. Percentage weight gain and percentage specific growth rate (SGR) were determined with the following formulas:

$$
\begin{aligned}
& \text { Weight gain }(\%)=[(\mathrm{Wf}-\mathrm{Wi}) / \mathrm{Wi}] \times 100 ; \\
& \text { SGR }(\%)=\frac{\ln \mathrm{Wf}-\ln \mathrm{Wi}}{\text { Number of experimental days }} \times 100
\end{aligned}
$$

Where, Wf is the final weight and Wi refers to the initial weight.

\section{Hematological and biochemical profile}

Hemoglobin concentration was determined using an automated hemoglobin reader (Accu-check Roche JB09927130, Germany). Total and differential white blood cell counts were determined with the methods put forward by Cheesbrough (2006). Blood electrolytes (sodium, potassium, chlorine, and bicarbonate), urea, creatinine, and C-reactive protein were determined according to the methods adopted by Reddy et al. (2011). Serum aspartate aminotransferase, alanine aminotransferase, and acid phosphatase were monitored according to the methods employed by Reitman and Frankel, (1957), Babson and Read, (1959) and Eissa and Zidan, (2010).

\section{Intestinal Escherichia coli load}

Intestinal washing with $1 \mathrm{ml}$ of PBS (pH 6.8) was performed weekly from 4 weeks of age until the end of experiment on sacrificed chicks (they were sacrificed by using inhalation anesthesia with chloroform, and cuting the cervical vein) in each group; then, $1 \mathrm{ml}$ of lavage fluid was serially diluted in $9 \mathrm{ml}$ peptone water and $0.1 \mathrm{ml}$ of suspension was cultured on EMB agar using the pour plate method. Colony-forming units from lavage cultures after $24 \mathrm{~h}$ incubation were used to determine the intestinal loads of E. coli (Pascual et al., 2009).

\section{Statistical analyses}

One-way ANOVA was applied to determine the means at $95 \%$ confidence interval. Tukey test was used for the comparison of means. P-value less than 0.05 was considered statistically significant.

\section{RESULTS}

\section{Identification and molecular typing of isolates}

The $E$. coli isolate with the most pathogenic effect on broiler chicks was identified as E. coli O157:H7 strain Sakai.

\section{Probiotic characteristics of Lactobacillus casei}

The probiotic screening of $L$. case $i$ was suggestive of an acceptable level of tolerance to acidic $\mathrm{pH}, 10 \% \mathrm{NaCl}$ and bile, as well as good adherence to xylene. In-vitro antibacterial activity evaluation showed that cell-free supernatant produced $10 \mathrm{~mm}$ diameter zone of inhibition, 
and crude bacteriocin exhibited $10.4 \mathrm{~mm}$ zone of inhibition diameter against APEC.

\section{Effect of administration of Lactobacillus casei on body weight}

Except for the infected and untreated group B, all other groups recorded weight gain. However, the highest weight gain was recorded in the control (uninfected chicks). The mean weights and specific growth rates of the chicks over the experimental period are shown in Figure 1 and Table 1, respectively.

Effect of Lactobacillus casei administration on hematological parameters and serum electrolytes of chicks

While the obtained results of the infected group indicated a significant decrease in hemoglobin levels, the groups treated with antibiotics and L. casei showed improved hemoglobin levels. There were also significant differences in the total white blood cell, neutrophils, and lymphocyte counts of infected and treated chicks. For these three parameters, the infected chicks had significantly $(\mathrm{p}<0.05)$ elevated counts (Table 2$)$. No significant $(\mathrm{p}>0.05)$ differences were recorded in eosinophil, basophil, and monocyte counts. For serum electrolytes, there were significant $(\mathrm{p}<0.05)$ increases in sodium, chlorine, and bicarbonate levels in treated groups,

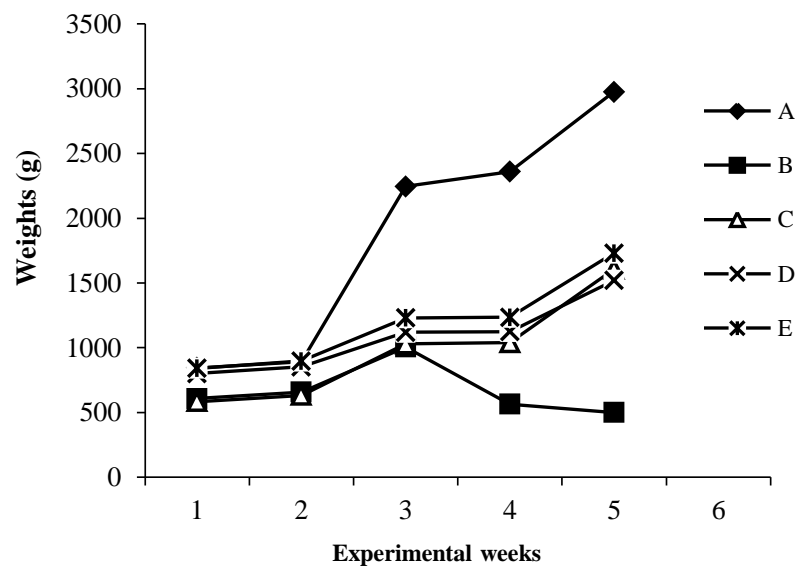

Figure 1. Comparison of mean body weights of broiler chicks infected with APEC in different treatment groups. APEC: Avian pathogenic E. coli. A: Healthy control, B: Infected with APEC and untreated chicks, C: Infected with APEC and treated with norfloxacin, D: Infected with APEC and treated with L. casei, E: Administered with $L$. casei $48 \mathrm{~h}$ before infection with APEC. compared to the infected group, but no increase in potassium. Urea, creatinine, and $\mathrm{C}$ - reactive protein levels were moderate when compared to those of the antibiotictreated and control groups (Table 3).

Effect of Lactobacillus casei administration on liver function of chicks

There was a marked increase in serum aspartate aminotransferase, alanine aminotransferase, and acid phosphatase values in the infected and untreated chicks, compared to the infected chicks treated with $L$. casei (Table 4). These differences were significant $(\mathrm{p}<0.05)$.

Effect of Lactobacillus casei administration on intestinal $E$. coli counts

There was a recorded steady increase in E. coli counts of infected and untreated chicks (B), from the first week to the fifth week of monitoring, compared with other groups. However, there was a slight decrease in intestinal E. coli count in the sixth week, which was still also the highest in value when compared to other groups. The antibiotic-treated chicks (C) showed a sharp decline in $E$. coli count after the first week of infection, and the same was observed in the probiotic-treated group (D). In the prophylactic group (E), E. coli growth was decreased, compared to other investigated groups (Figure 2).

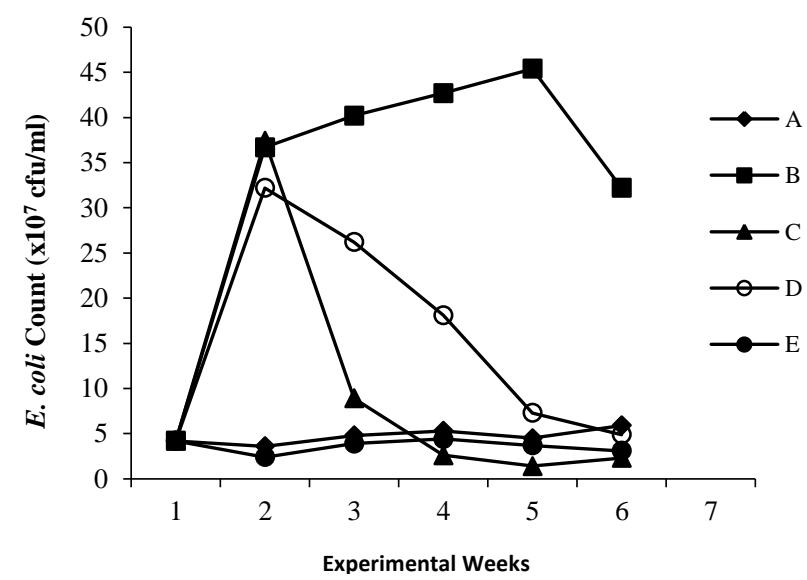

Figure 2. Intestinal E. coli counts of broiler chicks infected with APEC in different treatment groups. APEC: Avian pathogenic E. coli. A: Healthy control, B: Infected with APEC and untreated chicks, C: Infected with APEC and treated with norfloxacin, D: Infected with APEC and treated with L. casei, E: Administered with L. casei 48 h before infection with APEC. 
Table 1. Growth parameters of broiler chicks infected with APEC in different treatment groups

\begin{tabular}{|c|c|c|c|}
\hline \multirow{2}{*}{ Experimental Groups } & \multicolumn{2}{|c|}{ Weight gain } & \multirow{2}{*}{ Specific Growth Rate (\%) } \\
\hline & (g) & $(\%)$ & \\
\hline $\mathbf{A}$ & 2130.96 & 252.4 & 4.5 \\
\hline B & -109.26 & -17.9 & -0.7 \\
\hline $\mathbf{C}$ & 1019.54 & 174.1 & 3.6 \\
\hline D & 717.83 & 89.5 & 2.28 \\
\hline $\mathbf{E}$ & 887.80 & 105.4 & 2.57 \\
\hline
\end{tabular}

APEC: Avian pathogenic E. coli. A: Healthy control, B: Infected with APEC and untreated chicks, C: Infected with APEC and treated with norfloxacin, D: Infected with APEC and treated with L. casei, E: Administered with L. casei $48 \mathrm{~h}$ before infection with APEC.

Table 2. Hematological profile of broiler chicks infected with APEC in different treatment groups

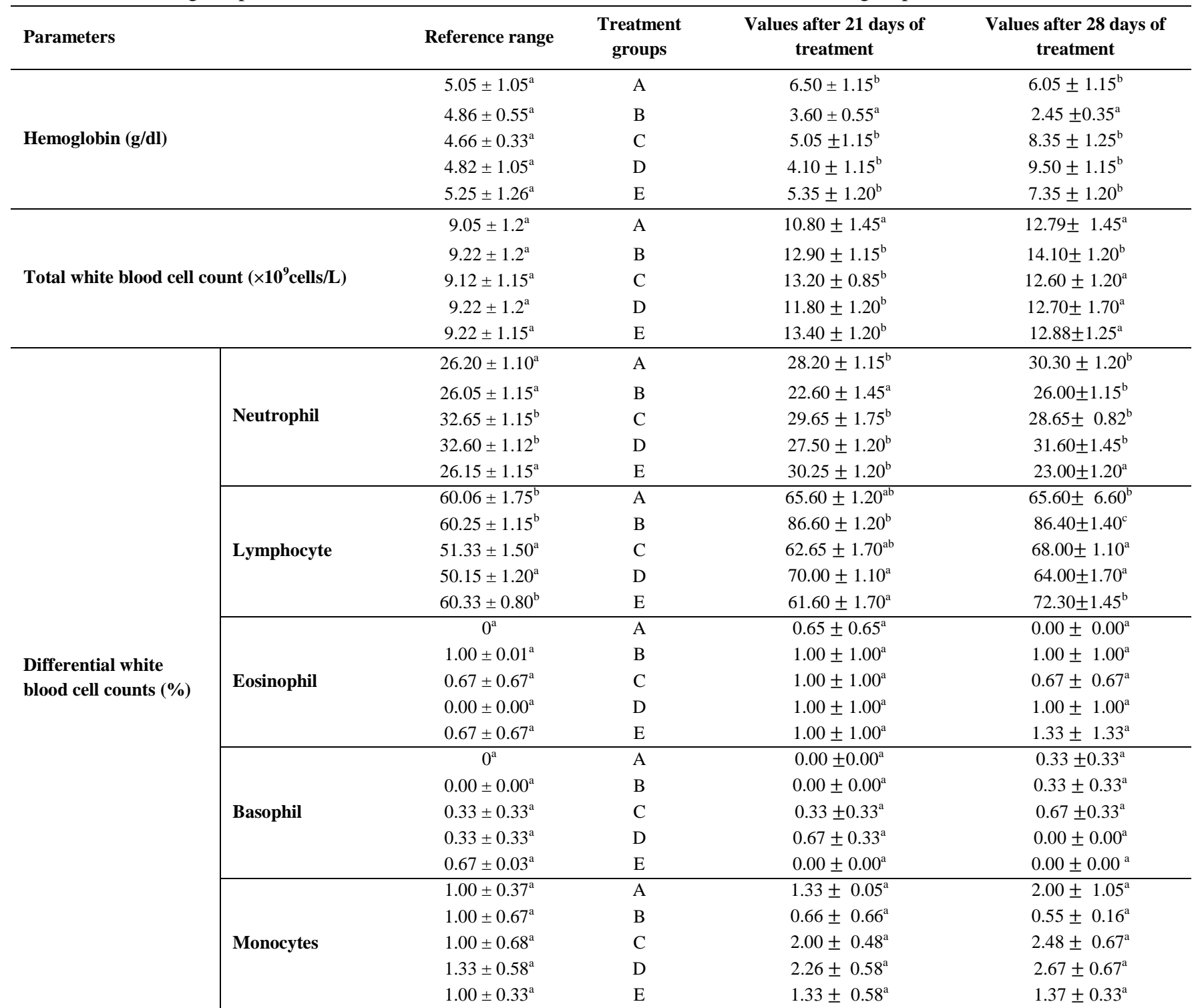

Means within the same column with different suffixes are significantly different (p<0.05). APEC: Avian pathogenic E. coli. A: Healthy control, B: Infected with APEC and untreated chicks, C: Infected with APEC and treated with norfloxacin, D: Infected with APEC and treated with $L . c a s e i$, E: administered with L. casei $48 \mathrm{~h}$ before infection with APEC. 
Table 3. Blood chemistry parameters of broiler chicks infected with APEC in different treatment groups

\begin{tabular}{|c|c|c|c|c|}
\hline Parameters & Reference range & $\begin{array}{c}\text { Treatment } \\
\text { groups }\end{array}$ & $\begin{array}{c}\text { Values after } 21 \text { days } \\
\text { treatment }\end{array}$ & $\begin{array}{c}\begin{array}{c}\text { Values after } 28 \text { days } \\
\text { treatment }\end{array} \\
\end{array}$ \\
\hline \multirow{5}{*}{ Sodium (MEq/L) } & $124.00 \pm 1.15^{\mathrm{b}}$ & $\mathrm{A}$ & $145.00 \pm 1.15^{\mathrm{c}}$ & $146.00 \pm 3.06^{\mathrm{c}}$ \\
\hline & $138.34 \pm 1.45^{\mathrm{c}}$ & B & $132.32 \pm 1.20^{\mathrm{a}}$ & $130.00 \pm 1.15^{\mathrm{a}}$ \\
\hline & $110.22 \pm 1.5^{\mathrm{a}}$ & $\mathrm{C}$ & $140.32 \pm 1.45^{\mathrm{b}}$ & $135.32 \pm 1.40^{\mathrm{ab}}$ \\
\hline & $136.00 \pm 1.15^{\mathrm{c}}$ & $\mathrm{D}$ & $134.00 \pm 1.15^{\mathrm{a}}$ & $136.00 \pm 1.15^{\mathrm{abc}}$ \\
\hline & $110.00 \pm 1.15^{\mathrm{a}}$ & E & $135.00 \pm 1.75^{\mathrm{a}}$ & $139.30 \pm 1.40^{\mathrm{b}}$ \\
\hline \multirow{5}{*}{ Potassium (MEq/L) } & $2.15 \pm 1.00^{\mathrm{a}}$ & $\mathrm{A}$ & $3.37 \pm 1.0^{\mathrm{a}}$ & $2.15 \pm 1.80^{\mathrm{a}}$ \\
\hline & $3.00 \pm 1.05^{\mathrm{a}}$ & B & $2.35 \pm 1.15^{\mathrm{a}}$ & $2.25 \pm 0.80^{\mathrm{a}}$ \\
\hline & $2.40 \pm 1.10^{\mathrm{a}}$ & $\mathrm{C}$ & $2.00 \pm 1.05^{\mathrm{a}}$ & $2.20 \pm 1.10^{\mathrm{a}}$ \\
\hline & $3.02 \pm 1.10^{\mathrm{a}}$ & $\mathrm{D}$ & $2.15 \pm 1.00^{\mathrm{a}}$ & $2.21 \pm 1.10^{\mathrm{a}}$ \\
\hline & $2.50 \pm 1.15^{\mathrm{a}}$ & $\mathrm{E}$ & $2.85 \pm 0.83^{\mathrm{a}}$ & $2.20 \pm 1.15^{\mathrm{a}}$ \\
\hline \multirow{5}{*}{ Chlorine (MEq/L) } & $94.06 \pm 1.15^{\mathrm{a}}$ & $\mathrm{A}$ & $138.00 \pm 1.15^{\mathrm{c}}$ & $145.00 \pm 1.15^{\mathrm{d}}$ \\
\hline & $105.55 \pm 1.40^{\mathrm{b}}$ & B & $115.60 \pm 1.40^{\mathrm{a}}$ & $105.00 \pm 1.15^{\mathrm{a}}$ \\
\hline & $96.20 \pm 1.75^{\mathrm{a}}$ & $\mathrm{C}$ & $120.65 \pm 1.75^{\mathrm{b}}$ & $135.00 \pm 1.15^{\mathrm{c}}$ \\
\hline & $116.60 \pm 0.06^{\mathrm{b}}$ & $\mathrm{D}$ & $120.00 \pm 1.15^{\mathrm{b}}$ & $130.30 \pm 1.45^{\mathrm{b}}$ \\
\hline & $116.28 \pm 1.08^{\mathrm{b}}$ & $\mathrm{E}$ & $122.00 \pm 1.15^{\mathrm{b}}$ & $135.30 \pm 1.20^{\mathrm{c}}$ \\
\hline \multirow{5}{*}{ Bicarbonate (MEq/L) } & $14.00 \pm 1.15^{\mathrm{a}}$ & $\mathrm{A}$ & $25.30 \pm 1.45^{\mathrm{a}}$ & $27.00 \pm 1.15^{\mathrm{c}}$ \\
\hline & $25.20 \pm 1.15^{\mathrm{b}}$ & $\mathrm{B}$ & $20.00 \pm 1.5^{\mathrm{a}}$ & $15.00 \pm 1.15^{\mathrm{a}}$ \\
\hline & $20.33 \pm 1.10^{\mathrm{b}}$ & $\mathrm{C}$ & $18.00 \pm 1.15^{\mathrm{a}}$ & $24.00 \pm 1.10^{\mathrm{b}}$ \\
\hline & $22.21 \pm 1.10^{\mathrm{b}}$ & $\mathrm{D}$ & $25.67 \pm 34.5^{\mathrm{b}}$ & $21.00 \pm 1.10^{\mathrm{b}}$ \\
\hline & $17.01 \pm 1.15^{\mathrm{a}}$ & $\mathrm{E}$ & $22.02 \pm 1.15^{\mathrm{b}}$ & $24.02 \pm 1.15^{\mathrm{b}}$ \\
\hline \multirow{5}{*}{ Urea (mg/dl) } & $4.19 \pm 2.81^{\mathrm{a}}$ & A & $6.06 \pm 1.52^{\mathrm{a}}$ & $7.02 \pm 0.78^{\mathrm{a}}$ \\
\hline & $4.92 \pm 0.78^{\mathrm{a}}$ & B & $11.96 \pm 1.34^{\mathrm{b}}$ & $17.41 \pm 3.22^{\mathrm{b}}$ \\
\hline & $4.33 \pm 0.59^{\mathrm{a}}$ & $\mathrm{C}$ & $8.87 \pm 3.02^{\mathrm{ab}}$ & $9.40 \pm 2.33^{\mathrm{a}}$ \\
\hline & $4.22 \pm 1.45^{\mathrm{a}}$ & $\mathrm{D}$ & $9.73 \pm 1.01^{\mathrm{ab}}$ & $9.83 \pm 1.15^{\mathrm{a}}$ \\
\hline & $4.31 \pm 1.12^{\mathrm{a}}$ & $\mathrm{E}$ & $9.41 \pm 0.89^{\mathrm{ab}}$ & $10.83 \pm 1.54^{\mathrm{a}}$ \\
\hline \multirow{5}{*}{ Creatinine (mg/dl) } & $0.13 \pm 0.03^{\mathrm{a}}$ & $\mathrm{A}$ & $0.83 \pm 0.60^{\mathrm{a}}$ & $0.51 \pm 0.31^{\mathrm{a}}$ \\
\hline & $0.24 \pm 0.33^{\mathrm{a}}$ & B & $2.55 \pm 1.96^{\mathrm{b}}$ & $1.19 \pm 0.16^{\mathrm{b}}$ \\
\hline & $0.22 \pm 0.25^{\mathrm{a}}$ & $\mathrm{C}$ & $0.52 \pm 0.19^{\mathrm{a}}$ & $0.57 \pm 0.25^{\mathrm{a}}$ \\
\hline & $0.13 \pm 0.17^{\mathrm{a}}$ & $\mathrm{D}$ & $0.65 \pm 0.08^{a}$ & $0.39 \pm 0.25^{\mathrm{a}}$ \\
\hline & $0.09 \pm 0.15^{\mathrm{a}}$ & $\mathrm{E}$ & $0.81 \pm 0.33^{\mathrm{a}}$ & $0.85 \pm 0.08^{\mathrm{a}}$ \\
\hline \multirow{5}{*}{ C-reactive Protein (mg/L) } & $4.00 \pm 1.15^{\mathrm{a}}$ & $\mathrm{A}$ & $8.00 \pm 3.46^{\mathrm{a}}$ & $10.00 \pm 3.46^{\mathrm{a}}$ \\
\hline & $4.17 \pm 1.33^{\mathrm{a}}$ & $\mathrm{B}$ & $20.00 \pm 3.42^{\mathrm{b}}$ & $18.00 \pm 6.00^{\mathrm{b}}$ \\
\hline & $4.31 \pm 0.23^{\mathrm{a}}$ & $\mathrm{C}$ & $8.67 \pm 2.31^{\mathrm{a}}$ & $6.00 \pm 0.00^{\mathrm{a}}$ \\
\hline & $4.45 \pm 0.15^{\mathrm{a}}$ & $\mathrm{D}$ & $8.00 \pm 3.06^{\mathrm{a}}$ & $6.00 \pm 0.01^{\mathrm{a}}$ \\
\hline & $4.93 \pm 0.05^{\mathrm{a}}$ & $\mathrm{E}$ & $10.00 \pm 1.46^{\mathrm{a}}$ & $8.00 \pm 3.42^{\mathrm{a}}$ \\
\hline
\end{tabular}

Means within the same column with different suffixes are significantly different $(\mathrm{p}<0.05)$. APEC: Avian pathogenic E. coli. A: Healthy control, B: Infected with APEC and untreated chicks, C: Infected with APEC and treated with norfloxacin, D: Infected with APEC and treated with $L$. casei, E: Administered with L. casei $48 \mathrm{~h}$ before infection with APEC.

Table 4. Liver function parameters of broiler chicks infected with APEC in different treatment groups

\begin{tabular}{|c|c|c|c|c|}
\hline Parameters & $\begin{array}{l}\text { Reference } \\
\text { range }\end{array}$ & $\begin{array}{l}\text { Treatment } \\
\text { Groups }\end{array}$ & $\begin{array}{c}\text { Values after } 21 \text { days } \\
\text { Treatment }\end{array}$ & $\begin{array}{c}\text { Values after } 28 \text { days } \\
\text { Treatment }\end{array}$ \\
\hline \multirow{5}{*}{ AST (IU/L) } & $24.12 \pm 3.33^{\mathrm{a}}$ & $\mathrm{A}$ & $33.33 \pm 7.64^{\mathrm{a}}$ & $35.00 \pm 7.55^{\mathrm{a}}$ \\
\hline & $33.86 \pm 10.24^{\mathrm{c}}$ & B & $74.33 \pm 7.02^{\mathrm{c}}$ & $88.00 \pm 6.64^{\mathrm{c}}$ \\
\hline & $34.32 \pm 3.35^{\mathrm{b}}$ & $\mathrm{C}$ & $52.67 \pm 6.86^{\mathrm{ab}}$ & $74.00 \pm 6.56^{\mathrm{b}}$ \\
\hline & $32.68 \pm 4.05^{\mathrm{b}}$ & $\mathrm{D}$ & $62.33 \pm 4.16^{\mathrm{b}}$ & $75.00 \pm 9.64^{\mathrm{b}}$ \\
\hline & $35.15 \pm 6.33^{\mathrm{c}}$ & E & $63.33 \pm 7.64^{\mathrm{b}}$ & $74.00 \pm 8.68^{\mathrm{b}}$ \\
\hline \multirow{5}{*}{ ALT (IU/L) } & $28.22 \pm 5.35^{\mathrm{a}}$ & A & $34.00 \pm 8.19^{\mathrm{a}}$ & $36.00 \pm 5.29^{b}$ \\
\hline & $31.00 \pm 6.16^{\mathrm{a}}$ & B & $63.67 \pm 6.66^{\mathrm{b}}$ & $48.67 \pm 6.66^{\mathrm{c}}$ \\
\hline & $29.66 \pm 3.13^{\mathrm{a}}$ & $\mathrm{C}$ & $47.67 \pm 4.93^{\mathrm{ab}}$ & $27.00 \pm 7.55 \mathrm{a}$ \\
\hline & $33.00 \pm 8.19^{\mathrm{b}}$ & $\mathrm{D}$ & $59.33 \pm 3.58^{\mathrm{ab}}$ & $33.33 \pm 2.58^{\mathrm{a}}$ \\
\hline & $33.33 \pm 7.26^{\mathrm{b}}$ & E & $55.67 \pm 4.73^{\mathrm{ab}}$ & $36.67 \pm 1.08^{\mathrm{a}}$ \\
\hline \multirow{5}{*}{ ACP (IU/L) } & $15.15 \pm 3.33^{\mathrm{a}}$ & $\bar{A}$ & $18.10 \pm 5.87^{\mathrm{a}}$ & $28.87 \pm 0.03^{\mathrm{a}}$ \\
\hline & $17.33 \pm 6.66^{\mathrm{a}}$ & B & $44.94 \pm 7.27^{\mathrm{c}}$ & $47.19 \pm 6.26^{\mathrm{b}}$ \\
\hline & $15.06 \pm 2.15^{\mathrm{a}}$ & $\mathrm{C}$ & $23.70 \pm 4.77^{\mathrm{a}}$ & $24.56 \pm 5.40^{\mathrm{a}}$ \\
\hline & $16.28 \pm 4.05^{\mathrm{a}}$ & $\mathrm{D}$ & $28.83 \pm 7.10^{\mathrm{b}}$ & $26.75 \pm 6.95^{\mathrm{a}}$ \\
\hline & $15.25 \pm 6.33^{\mathrm{a}}$ & $\mathrm{E}$ & $20.64 \pm 7.73^{\mathrm{a}}$ & $30.43 \pm 1.30^{\mathrm{a}}$ \\
\hline
\end{tabular}

Means within the same column with different suffixes are significantly different $(\mathrm{p}<0.05)$. AST: Aspartate transaminase; ALT: Alanine transaminase; ACP: Acid phosphatase, APEC: Avian pathogenic E. coli. A: Healthy control, B: Infected with APEC and untreated chicks, C: Infected with APEC and treated with norfloxacin, D: Infected with APEC and treated with L. casei, E: Administered with L. casei $48 \mathrm{~h}$ before infection with APEC. 


\section{DISCUSSION}

Attributes expressed by $L$. casei during probiotic screening suggest that it is a good probiotic organism as mentioned in studies conducted by Liu (2003) and Haben (2019).

Observation of the experimental groups showed a steady increase in the weight of uninfected chicks (A), compared with other groups. The infected, but untreated chicks (B) decreased in weight from about three weeks post-infection until the end of the experiment. On the other hand, the infected chicks treated with antibiotics and probiotic $L$. casei (C, D, E) showed weight gain, compared to untreated chicks (Figure 1 and Table 1) although the growth rate remained below that of the healthy control. Researchers have reported that probiotic administration in poultry usually results in weight gain as a result of improved absorption in the walls of the intestine and thus suggested that they could be adopted in place of antibiotics as growth promoters (Ezema, 2013; Vantsawa et al., 2017; Gulmez et al., 2019; Nugraheni et al., 2019). The findings in the current study support the claim that probiotics possibly affect weight gain in chicks, as seen in the mean body weight gain of chicks in group D.

Chicken colibacillosis is a localized or systemic infection caused by APEC. It is one of the common infectious diseases of farmed poultry and may manifest in several forms, including enteritis, septicemia, sub-acute pericarditis, salpingitis, peritonitis, and cellulitis (LutfulKabir, 2010). In the current study, disease progression was monitored in the chicks by the presence of watery and bloody diarrhea, which are signs of enteritis along with the analysis of haematological and biochemical parameters, which are useful as physiological indicators and diagnostic tools in chicks (Lloyd and Gibson, 2006; Keçeci and Çöl, 2011). The results obtained in the current study showed that there was a marked reduction in hemoglobin count in the infected and untreated chicks, compared to the infected chicks treated with $L$. casei (Table 2). There was also a significant difference in total white blood cell count, neutrophil, and lymphocyte counts between groups B and D; group B showed increased white blood cell and lymphocyte counts, compared to D. However, no significant differences were recorded in eosinophil, basophil, and monocyte counts. A severe reduction in red cell count is suggestive of anemia and may be attributed to the observable bloody diarrhea in the infected chicks. On the other hand, increased white blood cell and lymphocyte count, observed in the infected chicks, are usual indicators of the disease condition. All these signs were ameliorated in the current study by the administration of $L$. case $i$ probiotic, either as a treatment option, post-infection, or as a prophylactic measure. This is in line with previous studies that have reported the immune-boosting capacities of L. casei, L. delbrueckii, and L. plantarum (Kumar et al., 2010; Kechagia et al., 2013).

Oral administration of $L$. casei also produced some significant $(p<0.05)$ effects on some blood chemistry profiles of the broiler chicks. There was a marked reduction in sodium, chlorine, and bicarbonate values in the infected and untreated chicks compared to the infected chicks treated with $L$. casei. This indicates diarrhea severity and severe electrolyte loss and imbalance in infected untreated chicks but was not the case for the probiotic administered groups. There was also an observable difference in urea, creatinine, and C-reactive protein values between the two groups (B and D). There was proper creatinine clearance in the probiotic control and prophylactic groups, indicating proper kidney functions. There were also indications of poor liver function in the diseased chicks, probably as a result of systemic colibacillosis. However, the probiotic control and prophylactic groups had a normal liver function which implies that $L$. casei could not cause adverse effects in the liver function of chicks when taken orally.

A significant decrease in fecal E. coli counts reflects the probiotic effectiveness in controlling colibacillosis in the broilers. This finding could be further explained considering the report of Gogineni et al. (2013), which states that probiotic treatment of intestinal diseases cuts the infection cycle shorter almost like that of antibiotic treatment. As seen in Figure 2, chick groups treated with antibiotics and $L$. casei (C and D), respectively, showed a significant $(\mathrm{p}<0.05)$ reduction in fecal $E$. coli counts. In the groups administered $L$. casei prophylaxis, however, there was complete inhibition of infection, as chicks in that group (E) had similar counts as the healthy control (Figure 2). It is also noteworthy that the $L$. casei counts were sustained until the end of the experiment. This is in line with the report of Gaynor (2019) that L. casei can gut colonize and could provide some health benefits when used as a food ingredient.

\section{CONCLUSION}

The L. casei has positive probiotic qualities that can be used in the prevention and treatment of chicken colibacillosis. 


\section{DECLARATIONS}

\section{Competing interests}

Authors declare no competing interests.

\section{Authors' contributions}

Onyeka Michael Ikele conceptualized and carried out the research work, manuscript writing, and data analyses. Ifeoma Maureen Ezeonu assisted in the second supervision, data curation, and manuscript proof-reading. Chibuzo Nneka Umeh designed and supervised the research work before Ifeoma Maureen Ezeonu completed the supervision. All authors approved the final draft of the manuscript.

\section{REFERENCES}

Babson AI, and Read BS (1959). Kinetic colorimetric measurement of serum acid phosphatase level. Clinical Chemistry, 19 : 766-769. DOI: https://www.doi.org/10.1093/ajcp/32.1_ts.88

Center for Disease Control (CDC) (2014). General Information on Escherichia coli. Available at: https://www.cdc.gov/

Center for Disease Control (CDC) (2019). A one-healthchallenge. The interconnected threat of antibiotic resistance. https://www.cdc.gov/drugresistance

Cheesbrough M (2006). District Laboratory Practice in Tropical Countries-Part2. Cambridge University Press, New York, $2^{\text {nd }}$ edn. $\quad$ pp. 47-55. Available at: https://www.medbox.org/preview/5255d6e1-05d4-41a9beb2-02b60e695ecc/doc.pdf

De Preter V, VanhoutteT, Huys G, Swings J, De-Vuyst L, Rutgeerts P, and Verbeke K (2007). Effects of Lactobacillus casei Shirota, Bifidobacterium breve and Oligofructose-enriched Inulin on colonic nitrogen protein metabolism in healthy humans. American Journal of Physiology-Gastrointestinal and Liver Physiology, 292(1): 358-368. DOI: https://doi.org/10.1152/ajpgi.00052.2006

Dunne C, O’Mahony L, Murphy L, Thornton G, Morrisey D, O'Halloran S, Feeney M, Flynn S, Fitzgerald G, Daly C et al. (2001). In vitro selection criteria for probiotic bacteria of human origin: correlation with in vivo findings. American Journal of Clinical Nutrition, 73: 386-392. Available at: https://www.academic.oup.com

Dziva F, and Mark PS (2008). Colibacillosis in Poultry: Unravelling the Molecular Basis of Virulence of Avian Pathogenic E. coli in their Natural Host. Avian Pathology, 37(4): 355-366. DOI: https://www.doi.org/10.1080/03079450802216652.

Eissa FI, and Zidan NA (2010). Haematological, biochemical and histopathological alterations induced by Abamectin and Bacillus thuringiensis in male albino rats. Acta Biologica Hungarica, 61(1): 33-44. DOI: https://www.doi.org/10.1556/Abiol.61.2010.1.4
Ezema C (2013). Probiotics in animal production. Journal of Veterinary Medicine and Animal Health, 5(11): 308-316. DOI: https://www.doi.org/10.5897/JVMAH2013.0201

Gaynor P (2019). Conclusion of the expert panel: determination of the GRAS status of the use of Lactobacillus paracasei. Paracasei strain F-19 in conventional foods. Center for Food Safety and Applied Nutrition, 840: 1-64. Available at: https://www.fda.gov

Gogineni VK, Morrow LE, and Malesker MA (2013). Probiotics: mechanisms of action and clinical applications. Journal of Probiotic Health, 1(1): 1-11. DOI: https://www.doi.org/10.4172/jph.1000101

Gulmez M, Gulmez N, Bingol S, Deprem T, and Koral Tasci S (2019). The effect of dietary inclusion of probiotics on growth and intestinal morphology of broilers. Journal of World's Poultry Research, 9(1): 24-31. DOI: https://www.doi.org/10.36380/jwpr.2019.3

Haben F (2019). Probiotics and its potential role in poultry production- A review. Veterinary Medicine Open Journal, 4(2): 69-76. DOI: https://www.doi.org/10.17140/VMOJ-4$\underline{138}$

Hartmann HA, Wilke T, and Erdmann R (2011). Efficacy of bacteriocin-containing cell-free culture supernatants from lactic acid bacteria to control Listeria monocytogenes in food. International Journal of Food Microbiology, 146: 142-199.

DOI: https://www.doi.org/10.1016/j.ijfoodmicro.2011.02.031.

Holzapfel WH, Haberer P, Geisen R, Bjorkr R, and Schillinger U (2001). Taxonomy and important features of probiotic microorganisms in food and nutrition. American Journal of Clinical Nutrition, 73: 365-373. DOI: https://www.doi.org/10.1093/ajen/73.2.365s

Ikele MO, Ilikannu S, Obasi CJ, Okeke BC, Ikele BC, Nwakoby NE, Ukoha CC, Victor-Aduloju AT, and Aduloju T (2019). Antifungal activities of Alcaligenes faecalis palm wine isolate in mice model vaginal candidiasis. International Journal of Innovative Research and Development, $\quad 8(10)$ : $112-118 . \quad$ DOI: https://www.doi.org/10.24940/ijird/2019/v8/i10/

Ikele MO, Ezeonu IM, and Umeh CN (2020a). Prebiotic roles of Ocimum gratissimum extract in the control of colibacillosis in broilers. Journal of Animal Health and Production, 8(4): 206-211. DOI: http://dx.doi.org/10.17582/journal.jahp/2020/8.4.206.211

Ikele MO, Umeoduagu ND, Nwakoby NE, and Ogbukagu CM (2020b). Efficacy of probiotic Lactobacillus casei in biocontrol of E. coli $\mathrm{O} 157: \mathrm{H} 7$ in nono. International Journal of Innovative Research and Development, 9(2): 135-138. DOI: https://www.doi.org/10.24940/ijird/2020/v9/i2/FEB20066

Joshi VK, Sharma S, and Rana NS (2006). Production, purification, stability and efficacy of bacteriocin from isolates of natural lactic acid fermentation of vegetables. Journal of Food Technology and Biotechnology, 44(3): 435-439. DOI: https://hrcak.srce.hr/109971

Keçeci T, and Çöl R (2011). Haematological and biochemical values of the blood of pheasants (Phasianus colchicus) of different ages. Turkish Journal of Veterinary and Animal 
Sciences, $\quad 35(3)$ : 149-156. DOI: https://www.doi.org/10.3906/vet-0910-135

Kechagia M, Basoulis D, Konstantopoulou S, Dimitriadi D, Gyftopuolou K, Skarmoutsou N, and Fakiri EM (2013). Health benefits of probiotics. A review. ISRN Nutrition, Article ID 481651 . DOI: https://www.doi.org/10.5402/2013/48165

Kumar M, Kumar A, Nagpal R, Mohania D, Behare P, Verma V, Kumar P, Poddar D, Aggarwal PK, Henry CJK et al. (2010). Cancer-preventing attributes of probiotics: an update. International Journal of Food Sciences and Nutrition, $\quad 61(5)$ : 473-496. DOI: https://www.doi.org/10.3109/09637480903455971

Liu S (2003). Review article: Practical implications of lactate and pyruvate metabolism by lactic acid bacteria in food and beverage fermentations. International Journal of Food Microbiology, 83: 115-131. DOI: https://www.doi.org/10.1016/S0168-1605(02)00366-5

Lloyd S, and Gibson JS (2006). Haematology and biochemistry in healthy young pheasants and red-legged partridges and effects of spironucleosis on these parameters. Avian Pathology, 35(4): 335-340. DOI: https://www.doi.org/10.1080/03079450600821794

Lutful-Kabir SM (2010). Avian Colibacillosis and Salmonellosis: A closer look at epidemiology, pathogenesis, diagnosis, control and public health concerns. International Journal of Environmental Research and Public Health, 7: 89-114. DOI: https://www.doi.org/10.3390/ijerph7010089

Makut MD, Nyam MA, Amapu TY, and Ahmed A (2014). Antibiogram of bacteria isolated from locally processed cow milk products sold in Keffi metropolis, Nassarawa State, Nigeria. Journal of Biology, Agriculture and Healthcare, 4(4): 19-25. Available at: https://www.iiste.org

Nugraheni YR, Suryadi S, Prasetyo AF, and Awaludin A (2019). Evaluation of effects of novel probiotic feed supplement on the quality of broiler meat. Veterinary World, 12(11): 1775-1778.

DOI: www.doi.org/10.14202/vetworld.2019.1775-1778

Pascual L, Ruiz F, Giordano W, and Barberis L (2009). Vaginal colonization and activity of the probiotic bacterium Lactobacillus fermentum $\mathrm{L}_{23}$ in a murine model of vaginal tract infection. Journal of Medical Microbiology, 59(3):
360-364.

DOI:

https://www.doi.org/10.1099/jmm.0.012583-0

Radhakrishman S, Saravana BP, Seenivasan C, and Muralisankar $\mathrm{T}$ (2015). Effect of dietary replacement of fishmeal with Chlorella vulgaris on growth performance, energy utilization and digestive enzymes in Macrobrachium rosenbergii post larvae. International Journal of Fisheries and Aquaculture,7(5): 62-70. DOI: https://www.doi.org/10.5897/IJFA15.0471

Reddy VC, Amulya V, Lakshmi CH, Reddy DB, Pratima D, Thirupathi AT, Kumar KP, and Sengottuvelu S (2011). Effect of Simvastatin in Gentamicin induced nephrotoxicity in albino rats. Asian Journal of Pharmaceutical and Clinical Research, 5(1): 36-40. Availableat: https://www.innovareacademics.in/journal/indexphp/ajpcr

Reitman S, and Frankel S (1957). A Colorimetric method for the determination of serum Glutamic oxalacetic and Glutamic Pyruvic Transaminases. American Journal of Clinical Pathology, 28(1): 56-63. DOI: https://www.doi.org/10.1093/ajcp/28.1.56.

Ronnqvist D, Brusk U, Husmark U, and Hakansson E (2007). Lactobacillus fermentum Ess- 1 with unique growth inhibition of vulvo-vaginal candidiasis pathogens. Journal of Medical Microbiology, 56(11): 1500-1504. Available at: https://www.microbiologyresearch.org

Vantsawa PA, Umar T, and Bulus T (2017). Effects of probiotic Lactobacillus acidophilus on performance of broiler chicks. Direct Research Journals, 5(8): 302-306. DOI: https://www.doi.org/10.26765/DRJAFS.2017.DRJA16284 $\underline{589}$

Vesković Moračanin SV, Dukić DA, and Memiši NR (2014). Bacteriocins produced by Lactic acid bacteria- a review APTEFF, $45:$ 1-283. DOI: https://www.doi.org/10.2298/APT1445271V

World Health Organization (WHO) (2014). Antimicrobial resistance: global report on surveillance, Geneva, Switzerland: WHO Press, p. 256. Available at: https://www.who.int/antimicrobialresistance/publications/surveillancereport/en/ 